\title{
Tree Rings Record 100 Years of Hydrologic Change Within a Wetland
}

\section{WHAT ARE TREE RINGS?}

7 ree trunks grow wider from the continued divisions of thin layer of living cells just inside the bark. Some cells form new bark, but 1 most others give rise to concentric layers of wood (tree rings). In addition to strengthening the tree, rings carry water and minerals from the roots to the leaves. The age of a tree can be determined by counting the rings in the lower trunk because only one ring forms each year. Additionally, the widths of rings often indicate what environmental conditions were like during the tree's lifetime. For example, rings of trees growing on well-drained, upland soils usually are narrower during drought years and wider when rainfall is plentiful; the opposite may be true for some wetland trees exposed for long periods to saturated soil conditions. By measuring ring widths of old trees, scientists can estimate how conditions varied over hundreds or sometimes even thousands of years. Narrow rings sometimes also form when trees are damaged by floods, volcanic and glacial activity, defoliation by insects, and even earthquakes. Thus, tree-ring studies also can be used to document the occurrence of natural disasters in places where records are unavailable. A more recent application uses tree rings to study contamination of water, air, or soil by measuring the concentrations of heavy metals and other pollutants within the rings themselves.

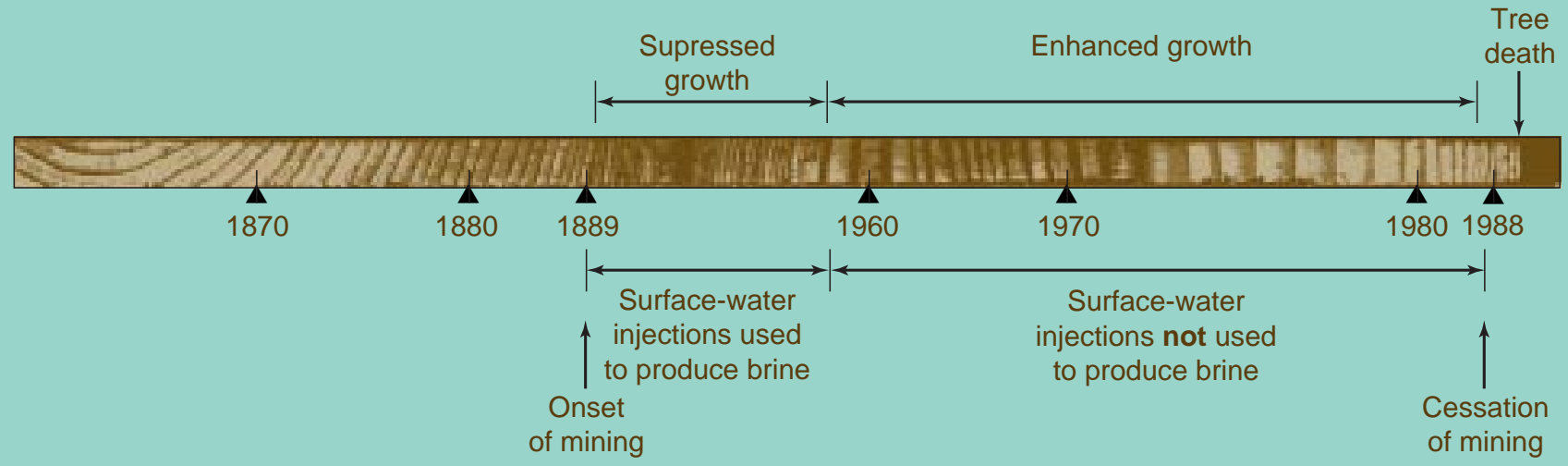

Figure 1. Photograph of core sample $(1.5 \mathrm{x}$ life size) removed from the oldest white pine that grew in the wetland.

The tree died in late 1995 or early 1996. (Photograph by D. Usher, USGS)

\section{INTRODUCTION}

$\mathrm{O}$ ne of the primary responsibilities of the Water Resources Division of the United States Geological Survey is to monitor the amount and quality of waters in our rivers, lakes, and wetlands. Hydrologists can evaluate these important resources in the present day, but how can they determine what conditions were like in past decades or even centuries? Moreover, are conditions part of a natural cycle or caused primarily by human activities? It is sometimes possible to answer these questions by examining the annual growth rings of trees (fig. 1). Each ring can be assigned an exact year of formation, and yearly differences in ring widths can be used to compare past and present conditions on a flood plain, along a river, or within a wetland. Thus, tree rings provide information that otherwise might be difficult or even impossible to obtain.

Hydrology and tree growth were investigated within a small wetland in the Tully Valley of central New York, about 20 miles south of Syracuse. In late 1994 it was noted that some wetland trees were dying, and local residents reported that flow of a small stream draining the wetland seemingly increased and became more brackish since the mid to late 1980s. The wetland is about 3 miles north of an extensive salt mining operation known to have degraded local water quality, but no effects of mining had been confirmed previously near the wetland. The oldest wetland trees started to grow before the onset of mining in 1889, and thus tree-ring studies were undertaken not only to investigate recent hydrologic change within the wetland, but also to search for evidence of any other changes during the last 100 years. 


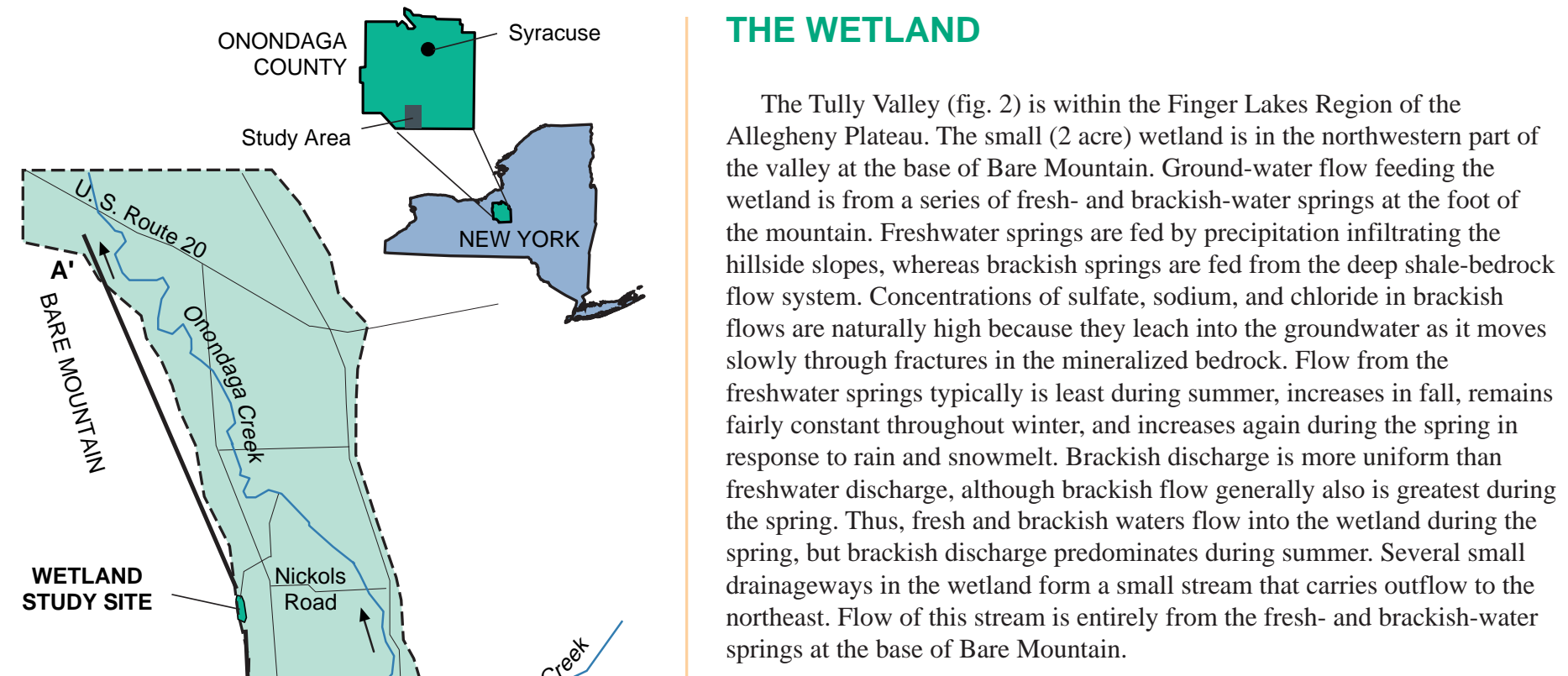

\section{HISTORY OF SOLUTION-BRINE MINING}

A considerable saltworks industry developed by the mid 1800s along the western side of Syracuse. Over-exploitation of local salt reserves spurred the discovery in the late 1880 s of salt layers approximately 1000-1400 feet below land surface at the southern end of the Tully Valley. Mining operations began in 1889 and continued until the late 1980s, during which approximately 200 million tons of salt were removed. In order to mine the salt, operators injected surface water into the salt layers through a series of wells and then lifted the dissolved salt (brine) to the surface. Company records from the turn of the century estimated that $40-60 \%$ of injected waters were "lost" to the surrounding bedrock and/or glacial deposits. Injection practices were abandoned in the late 1950s because it was determined that groundwater flow into the caverns were sufficient to dissolve additional salt deposits. Up to one billion gallons of brine per year were pumped after injection practices were abandoned. Mining activities were reduced greatly in 1986 and ended in 1988.

Removal of nearly 150 feet of salt caused the land surface to collapse in parts of the brine fields as early as the 1920s. Large collapses occurred during the 1940s, and surface subsidence of 5 to over 40 feet has occurred since the 1950s. No subsidence was documented as far north as the study wetland, however.

\section{TREE-RING ANALYSES}

White pine trees generally are clustered near the center of the wetland on moss-covered hummocks at slight elevations above the series of small drainageways. Only a few pines grow in northern and southern parts of the wetland. Pines range in age from 20 to 130 years, in diameter from 7 to 20 inches, and in height from 15 to 30 feet. Numerous trees were in poor health in late 1994, particularly within the central part of the wetland, and at least four died during the ensuing year. Two pencil-sized corings from each of 17 white pines were collected with a steel increment borer designed to extract samples of rings without harming the tree. Cores were placed to dry in paper drinking straws and subsequently sanded to make the rings easier to see. The rings of each paired cores were measured and crossdated with each other (the process whereby each ring is assigned an exact year of formation) and averaged together to form one composite ring-width series for each tree.
Figure 2. Map of the Tully Valley showing the location of solution-brine fields and study wetland.
BRINE FIELD 


\section{TREE GROWTH}

\section{A. During the Period of Injection-Mining}

Ring growth of white pines at poorly drained sites, such as the study wetland, would be expected to be less than that of upland-grown trees. However, study trees formed much narrower rings than expected, but only after the early 1890s (fig. 1). Moreover, these unusually narrow rings continued to be formed until about 1960. In other words, the long series of very narrow

\section{- B. After the Period of Injection-Mining}

A twenty year sequence of unusually wide rings began about 1960 or shortly thereafter (fig. 1), indicating that conditions for tree growth improved strikingly and quickly. The onset of this "growth release" in wetland pines coincides with closure of the eastern part of the brine field in 1957 and the rings coincides with the precise interval that surface-water injections were used to dissolve the salt and lift it to the surface. During this period much of the injected water "lost" to the bedrock flowed along northerlyrising fractures and discharged at the land surface, as the brackish springs at the study wetland (fig. 3). Saturated soil conditions reduced the amount of oxygen available to pine roots, thus stunting ring growth. Disease, damage, or climatic factors could

discontinuance of surface-water injection practices in the western part of the brine field a year or two later. Continued pumping of brine and the absence of injected waters reduced flow to the bedrock fractures and thus reduced the flow of brackish springs as far north as the wetland. Flow patterns of the precipitation-driven freshwater springs were not altered, however, resulting in the progressive drying of waterlogged soils have caused the formation of narrow rings, but not for nearly 70 years. Rather, the onset and duration of narrow ring growth of the oldest study trees suggest that the rate of brackish flows into the wetland increased dramatically in the early 1890 s and remained high until at least the late 1950s. As expected, other trees that started to grow after the onset of mining also formed unusually narrow rings during the entire interval of injection mining.

during summer and, thus, creating favorable conditions for tree growth. In other words the site during summer was probably more like an upland than a wetland. If this interpretation is correct, wetland trees that started to grow after 1960 would be expected to have very wide rings rather than the narrow rings typical of trees established during the interval of injection mining, and indeed this was the finding.

\section{- C. Since the Cessation of Mining}

The growth of some trees declined during the early 1980s, apparently as the result of regional drought. However, instead of recovering from drought when conditions improved in following years, many trees continued to grow even more poorly from the late 1980 s to the present (fig. 1). Some trees died during the mid 1990s and others show signs of poor health suggesting that they too may soon die. Although it might appear that the demise of trees is due simply to overwatering, this does not seem to be the case. Chemical analysis indicates that affected trees contain unusually high concentrations of chloride in rings that formed during the early to mid 1990s. Moreover, affected trees grow closest to the brackish springs, those intermediate in distance show mild symptoms, and those most distant appear healthy.

The cessation of brine withdrawals in 1988 reestablished flow to bedrock fractures in the mining area and to the brackish springs. Thus, the growth of trees again slowed as saturated soil conditions persisted longer into the growing season. Unlike irrigation of the wetland from lost injected waters, however, the new flows contained larger amounts of salt derived from the collapsed bedrock above the brine cavities. The demise of wetland trees seemingly is related more to this change in water quality than to the quantity of increased flows. To strengthen this contention, chloride was measured in the oldest trees in rings that formed before, during, and after mining. As expected, chloride concentrations were low in rings that formed before the onset of mining, higher in rings that formed during the 18901960 period of injection mining, lower again thereafter during the 1960-1986 period, and highest following the cessation of mining.

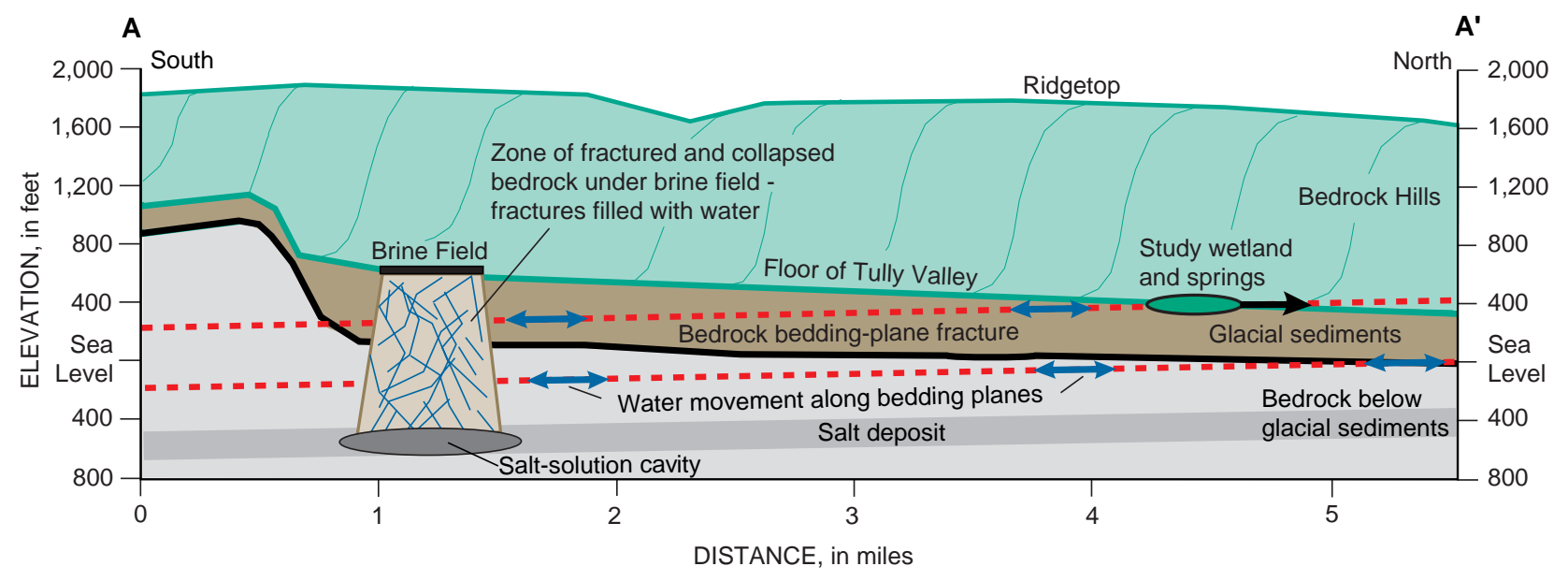

Figure 3. Schematic cross-section of the Tully Valley showing bedrock and bedding-plane fractures that provide a flowpath from the south to the north. 


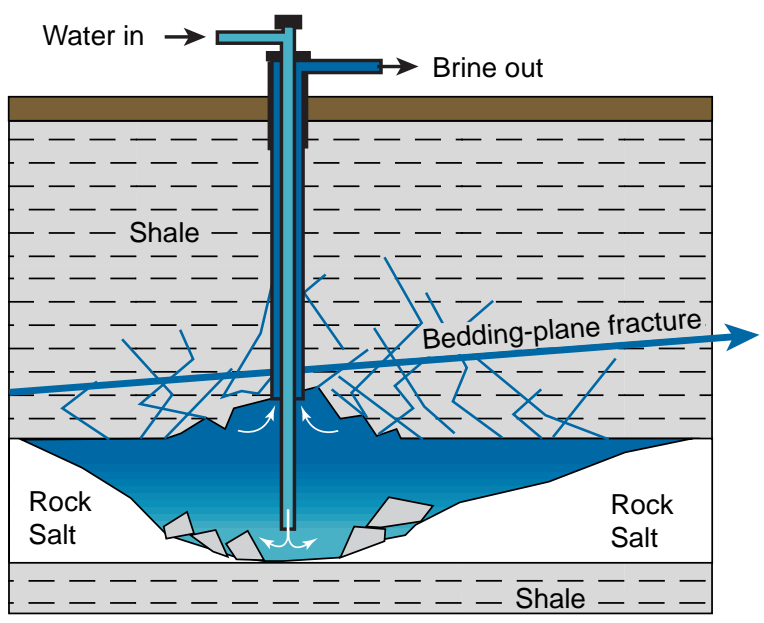

Figure 4. Solution-salt mining

The solution mining of salt in the late 19th century began with drilling a hole down to the salt layer, and the installation of two steel casings into the hole. Fresh water was pumped down the inside casing where the water dissolved the rock salt and produced a brine (salt water). The brine was "lifted" and later pumped up to land surface in the outside casing. As large amounts of rock salt were dissolved, the unsupported shale rock above the salt cavity began to break and fall into the salt cavern. As the cavern became larger, the shale bedrock continued to break and slowly fill the cavern with broken rock, which eventually caused subsidence at land surface. Initially, the subsidence was small and gradual, and generally unnoticed. Later, as the cavities became larger, the land-surface subsidence was greater and more noticeable.

\section{CONCLUSIONS}

Tree rings preserve evidence of three distinct episodes of hydrologic change within the wetland during the past century, at a location where no previous effects of salt mining had been reported. This study is one example of the U.S. Geological Survey's use of tree rings to investigate hydrologic conditions during both the past and present. For more information regarding additional tree-ring studies, please contact a Survey representative from one of the two addresses listed below.

T.M. Yanosky and W.M. Kappel

\section{Additional Reading}

Kappel, W.M., Sherwood, D.A., and Johnston, W.H., 1996, Hydrogeology of the Tully Valley and characterization of mudboil activity, Onondaga County, New York: U.S. Geological Survey Water-Resources Investigations Report 96-4043, 71 p.

Phipps, R.L., 1985, Collecting, preparing, crossdating, and measuring tree increment cores: U.S. Geological Survey WaterResources Investigations Report 85-4148, $48 \mathrm{p}$.

Yanosky, T.M., and Kappel, W.M., 1997, Effects of solution mining of salt on wetland hydrology as inferred from tree rings: Water Resources Research, v. 33, p. $457-470$.

\section{For More Information:}

Subdistrict Chief

U.S. Geological Survey

903 Hanshaw Road

Ithaca, New York 14850

Chief, Branch of Regional Research

U.S. Geological Survey

National Center, Mail Stop 432

Reston, Virginia 20192
This fact sheet and related information can be found on the World Wide Web at: http://ny.usgs.gov
Additional earth science information can be obtained by accessing the USGS"Home Page" on the World Wide Web at: http://water.usgs.gov

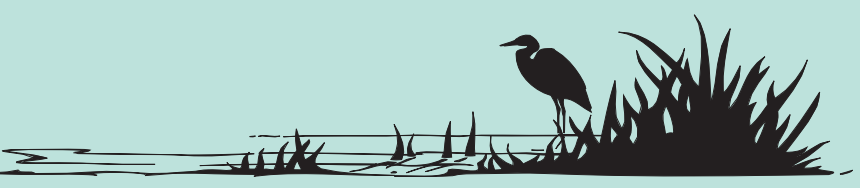

